\title{
RUSSIAN RESERVE FUND MANAGEMENT: PROBLEMS AND PROSPECTS
}

\section{Sergey Kirsanov}

Russian State Hydrometeorological University, St. Petersburg, Russia

Evgeny Safonov

Russian State Humanitarian University, Moscow (Domodedovo branch), Russia

\author{
Sandra Ramirez \\ Moscow State Institute of International Relations, Moscow, Russia \\ CMESTE \\ JEL Category: E42, G18
}

\begin{abstract}
The international experience on the use of state reserve funds for economic development approves that the infrastructure facilities deficit affects the development of non-energy sectors and holds the economic growth, in spite of the improving investment climate in the country. The effective bankroll investment of Russian Reserve Funds (the Reserve Fund and National Welfare Fund) is the integral part of the active state investment policy which facilitates lifting of the infrastructure restrictions. Generally, the countries establish reserve funds when their budget is highly dependent on market factors and global commodity prices. These funds have two functions. Firstly, the resources could be used to cover the budget deficit at the time of adverse conditions. Secondly, funds allow to accumulate extra export revenues and to prevent the Dutch disease when commodity prices increase. The state reserve fund is a special monetary fund which is used to stabilize the budget during budget revenues decreasing and for state long term purposes. Apart from resolving economic problems, the reserve fund have a political mission to prevent government expenditures growth. Traditionally, it is impossible to reduce quickly government expenditures after the drop in budget income. As a result, this situation entails large budget deficit, nonfulfillment of social obligations and the government debt default in terms of adverse market conditions. It is essential to improve the investment efficiency of the fund's resources for the Russian Reserve Funds (NWF and the Reserve Fund) best practice. The article is devoted to the issue of Russian reserve funds management.
\end{abstract}

Keywords: state reserve funds, National Welfare Fund (NWF), Central Bank of Russia, investment

\section{RESERVE FUNDS ESTABLISHMENT AND USE}

The address of the corresponding author:

Sergey Kirsanov

莑” ksaimr@mail.ru
In 2008 the Reserve Fund and National Welfare Fund were established after the subdivision of the Stabilization Fund. These Funds are filled out of 
the budget resources, which are derived from oil and gas revenues.

As a kind of financial reserves, reserve funds are characterized by some specific features:

- they are multi-zone applications and related to centralized social reserves;

- these funds have a huge influence on the reproduction process because they contribute to the sustainability of the economy as a whole and its sectors in case of emergency and unforeseen complications;

- funds are always legislative;

- they are universal in use as they are intended to cover any additional financial requirement of the budget in case of emergency and unforeseen complications. (Gryaznova, 2012)

The fund's form of spending depends on the functional purpose of resource allocation. The order of spending is established in the regulations of the Government of the Russian Federation, State executive branches and local authorities. On a quarterly basis they are required to inform the appropriate legislative (representative) authorities on the fun's expenditure. This system of the information makes possible the current control over the targeted and efficient fund's use.

Oil and gas revenues are formed by:

- tax on natural resources production (oil, combustible natural gases, natural gas liquids);

- export customs duties on crude oil;

- export customs duties on natural gas;

- export duties on goods produced from oil. (Minfin Rossii, 2016)

Annually a certain portion of these revenues in the form of an oil and gas is spent to budget expenditures financing. The value of oil and gas transfer approved by the Federal budget act for the financial year and planning period in absolute terms, calculated as the $3.7 \%$ of the GDP forecasted for the corresponding year.

All oil and gas revenues are accumulated in the Reserve Fund after the setting up of the oil and gas transfer. The regulatory value of the Reserve Fund is approved by the Federal budget law for the corresponding financial year and planning period in absolute terms of $10 \%$ of the forecasted GDP. Retained oil and gas revenues are transferred to NWF after filling the Reserve Fund up to the approved amount. ${ }^{1}$ Another source of the filling the Reserve Fund are its return on investment.

In 2012 the Russian Government has changed the procedure of filling the Reserve Fund and NWF. The essence of the new "fiscal rule" is following (Navoy \& Shalunova, 2014):

1. oil and gas revenues forecast is based on average oil price over the last 10 years;

2. "extra" revenues are accumulated in the Reserve Fund until it reaches $7 \%$ of GDP;

3. minimum $50 \%$ of the extra oil and gas revenues are transferred to NWF and the remaining funds are transferred for the realization of the infrastructure projects and other priorities after the fulfilling of the Reserve Fund;

4. in case of the law oil price the budget deficit is covered by the resources from the Reserve Fund. (Decree No. 699, 2013)

Nowadays the Reserve Fund is $4.3 \%$ of GDP. Therefore, the new revenues will be used to replenish this Fund. The unique source of NWF replenishment will be the return on its investment. It's important to mention that the dynamics of filling the Reserve Fund reflects the global market conditions of fuel and energy products and aims to transform the extra revenues from the foreign trade activity into the long-term savings of the economy. Russian Reserve Funds are used in compensatory and regulatory purposes. (Navoy \& Shalunova, 2014)

However, the model of the Russian Reserve Funds establishment and use is not optimum. Thus, the funds accumulation is an inefficient form of savings, due to the extremely low level of return on investment of Reserve Funds resources in terms of accelerating inflation.

Potentially, Reserve Funds resources could be used for the acquisition and development of producing and distributing infrastructure for the Russian companies abroad. These funds could facilitate the funding of the centralized international procurement of high-tech equipment,

${ }^{1}$ In accordance with (Putin, 2010) 
technology, etc. Nowadays, the replenishment of National Funds is a lever to expand the bank's funding base and public sector of developed countries. Although, they must be referred to solve Russian domestic problems.

\section{NWF ASSET MANAGEMENT}

The NWF asset management has two targets: the guard against Fund's loss and solid return on investment (ROI) in the long term. Considering these goals, the NWF asset management entertains the possibility of negative $\mathrm{ROI}$ in the short term. (Jeltsin, 1998)

The Ministry of Finance of the Russian Federation provides the Fund's asset management by the following means:

1. acquisition of foreign exchange and its allocation on Fund's foreign proceeds accounts in the Central Bank of the Russian Federation (US dollar, euro, pound sterling). The Central Bank of the Russian Federation pays the interest established in bank account agreement for the use of Fund's resources;

2. allocation of the Fund's reserves in foreign currencies and financial assets denominated in the Russian rubles and allowed foreign currencies (allowed financial assets). (Decree N955, 2007)

The Ministry of Finance manages NWF assets in accordance with the first method, that is, by allocation of foreign exchange on Fund's foreign exchange proceeds accounts in the Central Bank of the Russian Federation. The Central Bank of the Russian Federation pays the interest on arrears which is equivalent to the index yield. This index is generated by financial assets that could accommodate the reserves of NWF.

The Government of the Russian Federation has established the following requirements for such financial assets:

1. NWF reserves could be invested into the debt obligations in the form of foreign securities of the following countries: Austria, Belgium, UK, Germany, USA and others.

2. Debt obligations must meet the following requirements:

- foreign debt emitents must have a rating of long-term credit status rating not lower than level "AA-" on classification of rating agencies Fitch-Ratings or Standard \&
Poor's or which is not below "Aa3" on classification of rating agency Moody's Investors Service; (Decree No. 805, 2008)

- Russian debt emitents must have a rating of long-term credit rating not lower than "BBB-" on classification of rating agencies Fitch-Ratings or Standard \& Poor's or which is not below "Baa3" on classification of rating Agency Moody's Investors Service;

- maturities of debt securities are fixed, their terms of issue and circulation do not provide the right of their prior redemption (repayment);

- minimum and maximum maturities of debt securities are set by the Ministry of Finance and they have a mandatory nature;

- the volume of debt obligations in circulation denominated in Russian rubles amounts not less than to 1 billion rubles, etc.

3. NWF reserves could be accommodated in the debt obligations of following international financial institutions: Asian Development Bank (ABD); Council of Europe Development Bank (CEB); European Bank for Reconstruction and Development (EBRD); International Bank for Reconstruction and Development (IBRD), etc.

4. Corporate shares and units of investment funds should meet the following requirements: corporate shares should be listed at least on the one stock exchange; shares of foreign emitents must be included in the lists of securities which are used in the index computation of MSCI World Index and FTSE All-World Index.

5. Deposits of Vnesheconombank should comply with the following requirements: denominated in the Russian rubles, the US dollars, euros and the British pounds; the maximum allowable amount on the ruble account is 955 billion rubles etc.

6. The Ministry of Finance of the Russian Federation entitled to establish additional requirements for allowed financial assets within the limits established by the government of the Russian Federation. (Order No.3, 2008) 
The most acute are the issues of the sovereign funds and the NWF assets management strategy.

Russian sovereign funds reserves are placed into fund's proceeds accounts in the Central Bank of the Russian Federation in allowed foreign currency (US dollar, euro, pound sterling) based on the Bank account agreement between Federal Treasury and the Central Bank of the Russian Federation. The Central Bank of the Russian Federation pays the interest established in bank account agreement for the use of sovereign fund's resources. The Central Bank is the core agent of the Ministry of Finance on funds asset management. It is important to mention, that the existing system provides funds an exemption from seizure of foreign caption.

\section{RESERVE FUND'S PROBLEMS AND DEVELOPMENT PROSPECTS}

It's worth pointing out that the volume of the Russian Reserve Funds has decreased. Thus, on the 1 of March 2016 the total volume of the Reserve Fund amounted to 3 trillion 747,06 billion rubles (49,9 billion dollars), NWF amounted to 5 trillion 356,96 billion (71,34 billion dollars). (Interfaks, 2016) Nowadays the authorities of the Russian Federation actively use the Reserve Fund to cover the budget deficit. In 2016 2,137 trillion rubles could be used for these purposes. By the end of 2016 the Reserve Fund may remain 1,051 trillion rubles ( $31 \%$ of the Fund's reserves at the beginning of the year). (Minfin Rossii, 2016)

In 2017 the Government of the Russian Federation will have only three main sources to cover the budget deficit: The Reserve Fund balance, NWF resources and return on domestic investment.

The economic slowdown in Russia encouraged many Russian state-run corporations to apply to the authorities for NWF resources. Nevertheless, the crisis bailout plan deprived of the funding several ambitious projects. (Krivoshapko, 2015) Minimum 2 trillion rubles should be remained in the Reserve Fund by the end of 2018. (Krivoshapko, 2015)

As soon as the Government of the Russian Federation decided to allocate NWF resources in infrastructure, a lot of companies have demanded to increase the investment limit of $40 \%$ up to $50 \%$ or $60 \%$. As a result, competition for funds has increased drastically. In the mid-2014, the total amount of applications exceeded the size of NWF. In 2014 over a hundred applications came in, in 2015 only 12 applications were from the state-run corporation Rosneft. Rosneft applied for the compensation of external financing because of the sanctions. First of all, Rosneft made a request for 2,44 trillion rubles to develop 28 strategic projects (the total amount of NWF resources was about 3 trillion rubles). The Ministry for Economic Development received 28 separate applications from the company (1.3 trillion rubles) by January 2016 . Nowadays only 5 corporation's projects are approved (for 300 billion rubles).

The most persuasive lobbyists were the state-run corporation Rosatom and the Russian Direct Investment Fund (RDIF). In June 2014 the Government has set their individual quotas - 10\% of NWF, but not more than 290 billion rubles. RDIF was the first recipient of the Fund. In December RDIF received a little more than 5 billion rubles for two projects: elimination of "digital gap" in association with "Rostelecom" and implementation of "smart grid" in association with "Russian grids".

Unfortunately, these investments should wait. Sanctions and the crisis forced the authorities to reconsider their attitude to the Funds. It is obvious that infrastructure projects are long-run projects and a large part of the funds should be kept liquid in the situation of a complex geopolitical situation, sanctions and a foreign markets foreclosure.

In 2014 the oil price became half as low. The ruble fell against the dollar by $50 \%$ and the inflation increased to $11.4 \%$ (the highest rate since the crisis of $2008,13.3 \%$ ). GDP growth decelerated to $0.6 \%$ (the lowest rate since 1999 , excluding the crisis year of 2009). Russia is in a very difficult situation. In the current situation the Reserve Fund will be exhausted in two years. According to the Ministry of Finance, 3.2 trillion rubles were necessary to cover the budget deficit and 1.16 trillion might be spent in 2016. NWF resources will be spent to cover the budget deficit after the exhaustion of the Reserve Fund.

The President decided be the main decision maker. The President's permission will be necessary to invest NWF resources. The Government's decision was enough earlier. (Titov, 
2015) The President ordered to invest into six projects: The Central Ring Road, the Baikal-Amur Mainline, the Atomic Power Station "Hanhikivi-1" in Finland, elimination of "digital gap", "Yamal LNG" (liquefied natural gas) and the purchase of locomotives for Russian Railways. Thus, the President has approved investments of just over 600 billion rubles. Together with subordinated deposits of Vnesheconombank (including the crisis bailout plan), the investments in shares of banks and 5 billion rubles, previously invested in the projects of RDIF, would exceed one third of NWF volume by the 1 March. The amount of investment is reduced in some projects and order is changed. For example, only the first and the fifth sections of the Central Ring Road are approved to invest. In the next 10-15 years NWF resources might be required for post-employment benefits. The return on investment might be extremely low and its use to support the pension system or to implement the crisis bailout plan will be impossible.

On the one hand, the amount of NWF resources has increased due to the ruble devaluation. Last year it increased by 1.5 trillion rubles. On the other hand, the ruble depreciation encourage inflation, that will entail an additional indexation of pensions. In such uncertain situation it is impossible to claim that the reserves will be enough. It should be kept in mind that existing recession leads to the higher unemployment rate. Inevitable, this situation will reduce the pension contributions and expand the Pension fund deficit. The pension system problems will increase. (Titov, 2015)

\section{RECOMMENDATIONS ON NWF RESOURCES USE}

During the process of generating the recommendations on the use of NWF resources for the economic development it is necessary to consider that the deficit of infrastructure facilities, which provides the strongest negative influence on the development of non-energy sectors, becomes a main factor that affects the economic growth in the context of investment environment improvement. The effective investment of NWF resources is the integral part of the active government policy which is necessary to remove infrastructure restrictions.
The Fund investment should be based on the principles of diversification and reliability of financial instruments. In our opinion, it is useful to involve specialized financial institutions into the Fund's asset management.

We believe that the NWF purpose is not to cover the deficit of the Russian Pension Fund in the coming years, but to be capable to ensure the financial sustainability of the Russian Pension Fund in the future. The optimum alternative is to accumulate NWF resources in the sufficient amount to cover the deficit of Russian Pension Fund in the future from the NWF's asset management.

It seems appropriate to provide the possibility to invest funds into domestic risk-free financial instruments, such as debentures and corporate shares, as well as into units of investment funds.

The investment in these instruments will ensure the long-term investment inflow to the Russian economy (but bank deposits and bank balances in Russian banks and credit organizations are short and medium -term resources).

Nowadays, the Ministry of Finance of the Russian Federation does not have any proposals on the merger or transformation of the Reserve Fund and NWF. In our opinion, it is useful to merge the Reserve Fund with NWF and to manage them as a single instrument.

Active asset management might ensure maximum return at a reasonable risk level. Thus, in our opinion, the following is necessary for the funds asset management:

- the long-term strategy of funds generation and use,

- the qualified investment management,

- the political independence,

- the protection from inflation,

- the universal method of operations efficiency analysis.

\section{CONCLUSION}

We believe that the mechanisms of funds disbursement for long-term economic development are still crude. In our opinion, the most acute problems, among the problems of funds generation and use, are: 
- the lack of a clear strategy for the asset management which may ensure the soundness and increase of the funds ' assets;

- the information on the use of the funds is not in the public access, thus, it is difficult to determine the real effectiveness of the funds asset management.

From our point of view, the bailout plan should include the revision of the NWF use in favor of domestic long-term investment and investments in infrastructure projects.

It is necessary to increase the return on funds investment for the funds effective functioning. We propose the following options to improve the Russian Reserve Funds efficiency and, as a consequence, their return on investment:

- to invest in projects which will increase living standards and personal income (the investment in "national welfare": the construction of stadiums, sports grounds, centers of education and retraining);

- to invest more than $10 \%$ of funds in foreign debt obligations with a higher risk level;

- to invest around $10 \%$ of funds in stocks, bonds, private funds, infrastructure companies and real estate, taking into consideration the experience of foreign funds;

- to improve the competitiveness of nonresource industries in the long term (one of the main problems of the Russian economy is the resource curse, thus the development of high technologies, agriculture, tourism and other industries will make Russian producers more competitive at the global market and will make the economy less dependent on global oil prices);

- the co-financing of major investment projects (for example, Transsib) is necessary for the economic recovery and infrastructure development in Russia;

- the rules, mechanisms and criteria for funds spending, as well as the extent of responsibility of authorities for misuse of reserve funds should be in a public use.

Moreover, in our point of view, it is necessary to think about the funds asset management by specialized financial institutions. In our opinion, the foreign experience investigation of reserve funds generation and use will facilitate implementing of this experience in the Russian Federation.

\section{WORKS CITED}

Decree N955. (2007, Dec 29). Order of the Government of the Russian Federation N955. Retrieved from cis-legislation.com: http://cis-legislation.com/document.fwx?rgn=20723

Decree No. 699. (2013, Aug 14). Order of teh Government of the Russian Federation. Retrieved from cis-legislation.com: http://cis-legislation.com/document.fwx?rgn=61906

Decree No. 805. (2008, Nov 06). The decree of the Government of the Russian Federation of 6 November 2008 No. 805. Retrieved from Ministry of Finance of the Russian Federation: http://www1.minfin.ru/ru/nationalwealthfund/legalframework/

Gryaznova, A. G. (2012). Finance. Moscow: Finance and statistics.

Interfaks. (2016, Mar 16). Minfin ne soglasilsya pogasit' gosdolg sredstvami Rezervnogo fonda. Retrieved from movosti@mail.ru: https://news.mail.ru/economics/25144832/?frommail=1/

Jeltsin, B. (1998, July 31). The Budget code of the Russian Federation, Chapter 13.2, article 96.11, clause 2. Retrieved from Garant: http://www1.worldbank.org/publicsector/pe/BudgetLaws/Budget_Code_Russia_Eng1998.pdf

Krivoshapko, Y. (2015, Sep 16). Minfin sokhranit ob"yem Rezervnogo fonda na urovne 2 trillionov rubley. Retrieved from Rossiyskaya gazeta: https://rg.ru/2015/09/16/fond-site-anons.html

Minfin Rossii. (2016, Apr 10). Formirovanie. Retrieved from Ministerstvo ffinansov Rossijskoj Federacii: http://old.minfin.ru/ru/reservefund/accumulation/ 
Minfin Rossii. (2016, Jun 01). Informatsionnoye soobshcheniye o rezul'tatakh razmeshcheniya sredstv Rezervnogo fonda i Fonda natsional'nogo blagosostoyaniya. Retrieved from Minfin Rossii: http://www.minfin.ru/ru/perfomance/nationalwealthfund/\#

Navoy, A. V., \& Shalunova, L. I. (2014). Rezervnyy fond i Fond natsional'nogo blagosostoyaniya Rossii v mezhdunarodnoy sisteme suverennykh fondov. Den'gi i kredit(2), 26-33.

Order No.3. (2008, Jan 16). Order of the Ministry of Finance of the Russian Federation from January 16, 2008 of No.3. Retrieved from Ministry of Justice Russian Federation: http://old.minfin.ru/en/reservefund/management/

Putin, V. (2010, Sept 30). On amendments to the Budget code of the Russian Federation and other legislative acts of the Russian Federation. Retrieved from Global-Regulation: https://www.global-regulation.com/translation/russia/2946361/on-amendments-to-the-budgetcode-of-the-russian-federation\%252c-article-6-of-the-federal-law-\%2526quot\%253bonamendments-to-the-budget-code-of-the-russian-f.html

Titov, S. (2015, Mar 05). Zanachka natsii: nadolgo li khvatit Fonda natsional'nogo blagosostoyaniya. Retrieved from RBK: http://www.rbc.ru/finances/05/03/2015/54f73f9a9a794746bb1165ff

Received for publication: $\quad 01.04 .2016$

Revision received: $\quad 01.06 .2016$

Accepted for publication: $\quad 10.06 .2016$

\section{How to cite this article?}

Style - APA Sixth Edition:

Kirsanov, S., Safonov, E., \& Ramirez, S. (2016, July 15). Russian reserve fund management: Problems and prospects. (Z. Čekerevac, Ed.) MEST Journal, 4(2), 113-119. doi:10.12709/mest.04.04.02.12

Style - Chicago Sixteenth Edition:

Kirsanov, Sergey, Evgeny Safonov, and Sandra Ramirez. 2016. "Russian reserve fund management: Problems and prospects." Edited by Zoran Čekerevac. MEST Journal (MESTE) 4 (2): 113-119. doi:10.12709/mest.04.04.02.12.

Style - GOST Name Sort:

Kirsanov Sergey, Safonov Evgeny and Ramirez Sandra Russian reserve fund management: Problems and prospects [Journal] // MEST Journal / ed. Čekerevac Zoran. - Belgrade : MESTE, July 15, 2016. - 2 : Vol. 4. - pp. 113-119.

Style - Harvard Anglia:

Kirsanov, S., Safonov, E. \& Ramirez, S., 2016. Russian reserve fund management: Problems and prospects. MEST Journal, 15 July, 4(2), pp. 113-119.

Style - ISO 690 Numerical Reference:

Russian reserve fund management: Problems and prospects. Kirsanov, Sergey, Safonov, Evgeny and Ramirez, Sandra. [ed.] Zoran Čekerevac. 2, Belgrade : MESTE, July 15, 2016, MEST Journal, Vol. 4, pp. 113-119. 